\title{
Defining Urban Ecology and the Connection to Urban Forestry
}

\author{
Fischer Burnell C* \\ Indiana University, USA
}

Submission: February 21, 2017; Published: February 27, 2017

"Corresponding author: Fischer Burnell C, Clinical Professor Emeritus, School of Public and Environmental Affairs, Indiana University, Bloomington IN, USA, Email: bufische@indiana.edu

\section{Opinion}

When I arrived at Indiana University in 2005 as a new faculty member, my rural forestry background wasn't the best fit for my 4 course per year teaching assignment. My focus quickly shifted to developing an urban forestry course. I started teaching Urban Forest Management in spring 2006 with 18 students enrolled and have offered the course annually. Enrollment is now capped at 40 students with a mix of undergraduate students (BS Environmental Management concentration) and Master of Science in Environmental Science students. In 2010, the master's students asked me to develop a second more science oriented course. I settled on a graduate student course in Urban Ecology. After five offerings it's developed into a solid "readings in urban ecology" course with a mix of topics and in-person/Skype interviews with researchers and educators. Urban ecology can be defined as the relation of all living organisms with each other and their surroundings in the context of an urban environment. This discipline differs from other fields of ecology because the urban ecosystem is physically dominated by humans and manmade structures in every aspect. This is generally clarified by using the term "social-ecological system" to define an urban area with the emphasis on social (aka, humans) front and center. A common theme permeating urban ecology is to ask whether an article or practice or program is urban ecology "in", "of" or "for" the city. I'll briefly explain what this means and how I believe it can connect with arborists, urban foresters and urban greening activists.

\section{Urban ecology "in" the city}

Refers to studying the ecology of place within a city, such as a specific wetland, forest patch or other natural area. Arborists can align easily with this concept as they focus on the care of a specific tree or small group of trees. Urban foresters often focus on woodland patches or city parks.

\section{Urban ecology "of" the city}

Refers to the whole city or greater metropolitan area. This thinking aligns more with urban foresters who inventory or keep records on a city's trees or tree canopy, and prepare/implement plans to address the sustainability of the urban forest. Arborists may be hired to treat city trees for a specific insect (EAB, ALB) or disease (Dutch Elm Disease).

\section{Urban ecology "for" the city}

How some ecologists view outcomes of their research programs. How do they make a difference via influencing urban natural resources management and policy/governance to improve and//or sustain the urban ecosystem? From an urban forestry perspective this expands thinking beyond arborists and urban forestry just planting or managing trees because "trees are good", to managing trees for storm water and urban heat island management, increasing habitat for pollinators, etc., etc. Andit includes a broad array of people such as urban greening nonprofits, planners, city park directors and others who plant/ maintain trees, in decision-making and implementation so as to improve community support for urban trees at very local levels (street blocks, neighborhoods, etc.) to city government itself. What I've learned through my involvement with urban ecology is that urban trees provide much of the structure for the urban ecosystem (streetscapes with trees, parks and other natural areas covered with trees and canopy cover of the city). Urban ecology helps us connect the various groupings of urban trees into ecosystems from the very local level "in" the city to the whole city ("of") and then connect with those actively engaged in striving to make a city more sustainable, and adaptable for climate change, etc. This results in arborists and urban foresters thinking beyond just the trees and "for" the city. 


\section{Your next submission with Juniper Publishers will reach you the below assets}

- Quality Editorial service

- Swift Peer Review

- Reprints availability

- E-prints Service

- Manuscript Podcast for convenient understanding

- Global attainment for your research

- Manuscript accessibility in different formats ( Pdf, E-pub, Full Text, Audio)

- Unceasing customer service

Track the below URL for one-step submission https://juniperpublishers.com/online-submission.php 